\title{
A DEFENCE OF SKEPTICAL THEISM
}

\author{
Nicola Salvatore \\ https:/ / orcid.org/0000-0002-7947-6233 \\ Universidade do Vale do Rio dos Sinos - UNICAMP, Escola de Humanidade \\ Department of Philosopby \\ São Leopoldo, R.S. \\ Brazil \\ nicolaclaudiosalvatore@googlemail.com
}

\author{
Article info \\ CDD: 149.73 \\ Received: 23.07.2021; Accepted: 15.08.2021 \\ https://doi.org/10.1590/0100-6045.2021.V44N4.NS
}

\section{Keywords \\ Problem of Evil \\ Skeptical Theism}

\begin{abstract}
According to The Evidentialist problem of Evil, the existence of disproportionate, prima facie gratuitous evil and suffering in the world is enough evidence against the existence of the Omnipotent, Perfectly Loving, Omniscient God of Classical Theism. A contemporary way of dealing with this argument is Skeptical Theism, for which the very fact that there is an huge amount of evil that looks gratuitous to us does not mean that we can reasonably believe whether this evil is indeed gratuitous or not. In this paper, I present and discuss a number of influential criticisms against this view according to which a proponent of Skeptical Theism will be forced to accept a number of unpalatable skeptical conclusions. I argue that this is not the case.
\end{abstract}

\section{The Evidential Problem of Evil and Skeptical Theism}

The Evidential Problem of Evil, namely the view for which the existence of prima facie, gratuitous evil in the world 
is incompatible with the existence of an Omnipotent, Omniscient, All Loving God such as the God of Classical Theism, can be stated as follows:

E1 There exist instances of intense suffering which an omnipotent, omniscient being could have prevented without thereby losing some greater good or permitting some evil equally bad or worse.

E2. An omnipotent, wholly good being would prevent the occurrence of any intense suffering it could, unless it could not do so without thereby losing some greater good or permitting some evil equally bad or worse

E3. There does not exist an omnipotent, omniscient, wholly good being (Rowe 1979)

The important aspect of this argument to notice is that it focuses on gratuitous evil: that is to say, on cases of evil which are so extreme, shocking and painful that it is almost impossible to understand why an all loving all powerful God would permit them and exactly which good, if any, would be lost had God prevented them.

A contemporary, influential way of dealing with E1) is Skeptical Theism (henceforth ST). Roughly, the main thesis of ST can be stated as follows: due to our cognitive limitations, we cannot know whether

E1 There exist instances of intense suffering which an omnipotent, omniscient being could have prevented without thereby losing some greater good or permitting some evil equally bad or worse. 
That is to say, according to the proponents of ST from the very fact that the various evils of the world looks gratuitous to $u s$, and thus incompatible with the existence of the God of Classical Theism, we cannot infer that these evils are indeed gratuitous; they might, or might not, be gratuitous, we are not in a position to judge whether E1) is true or not.

According to the proponents of ST, this is for a number of reasons. In the recent literature on ST, we can find at least three arguments in support of this view, namely the Parent Analogy, the Argument from Complexity and the Condition on Reasonable Epistemic Access, or CORNEA.

The Parent Analogy (henceforth PA) goes as follows. Just as we expect a small child to be blind to the reasons an adult has for allowing her to suffer justified pain, so we should expect that we will be blind to the reasons God has for allowing our justified suffering (Wyskra 1984).

That is to say, compared to am Omniscient, All Powerful Being human beings are no different from a newborn; as a newborn, due to the "constitutive" limitations of his cognitive apparatus, cannot possible understand the reasons behind the actions of his parents that looks prima facie "gratuitously evil" to him (i.e. hey leave him alone to go to work in order to feed him, they take him to doctor order to receive vaccines etc.) human beings are constitutively unable to understand whether the evils that looks gratuitous to us are indeed gratuitous or not.

A second argument in support of ST is the Argument from Complexity. Roughly, this view states that given the complexity of the interdependence of apparently trivial and meaningful events, we are in no position to say whether an event $\mathrm{x}$ is gratuitous or whether it does play an important role in the, let's say, Big Scheme of things. As Durston puts the matter: 
On the night that Sir Winston Churchill was conceived, had Lady Randolph Churchill fallen asleep in a slightly different position, the precise pathway that each of the millions of spermatozoa took would have been slightly altered. As a result...Sir Winston Churchill, as we knew him, would not have existed, with the likely result that the evolution of World War

II would have been substantially different... (2000, p. 66)

In other words, it would prima facie appear that there is no good reason to prefer sleeping in one position rather than another. But given the specifics of human reproduction, this assumption is unwarranted and-in this case-plausibly false; had Lady Churchill spelt in a different way, Sir Winston Churchill would not have existed. Thus, an apparently trivial event could play, and indeed has played, a pivotal role in the history of mankind. More generally,the proponents of the Complexity Argument extract the following moral from this story: the fact that we cannot see a reason for $\mathrm{x}$ is not indicative of whether or not there is any such reason.

Accordingly, argues Durston, from the very fact "we can see no reason to allow this evil" we cannot infer "there is no reason to allow this evil.

A third line of reasoning to defend the main thesis of ST is Wyskra's Condition on Reasonable Epistemic Access, or CORNEA for short (Wyskra, 1984). CORNEA's can be sketched as follows:

Inferences from "I see no X" to "There is no X" are justified only if it is reasonable to believe that if there were an X, I would likely see it. 
For instance, the inference from "I see no elephant in my office" to "There is no elephant in my office" is licensed by CORNEA since I reasonably believe that if there were an elephant in my office, I would likely see it.

But, argues Wyskra, it is not reasonable for us to think that if an Omniscient, Omnipotent God had reasons for allowing any particular evil ( that is to say, not evil in general but a particular instance of evil that looks at lest prima facie gratuitous to us), we would be aware of it. Thus, CORNEA says that the inference from "I see no reason for allowing this instance of evil" to "There is no reason for allowing this instance of evil" is invalid.

A second argument goes as follows. According to

Bergmann (2001) the inductive move from "I see no X" to "There is no X" is warranted only if it is reasonable for me to believe that my inductive sample of X's is representative of the whole. For example, one should not rely on inductive evidence to conclude that all crows are black unless it is reasonable to assume that one's sample of crows is representative of all crows.

In the case of the evidential Problem of evil, the inference from "I can see no reason to allow this evil" to "There is no reason to allow this evil" is justified only if it is reasonable for one to believe that the sample of reasons currently understood is representative of all of the reasons that are. But as we have no reason, due to our cognitive limitations, to believe that the sample of reasons currently understood to allow or not allow a certain evil $\mathrm{x}$ are representative of all of the reasons there are, then the inference from "I can see no reason to allow this evil" to "There is no reason to allow this evil" is not justified. In a more formal way: 
(ST1) We have no good reason for thinking that the possible goods we know of are representative of the possible goods there are

(ST2) We have no good reason for thinking that the possible evils we know of are representative of the possible evils there are.

(ST3) We have no good reason for thinking that the entailment relations we know of between possible goods and the permission of possible evils are representative of the entailment relations there are between possible goods and the permission of possible evils.

(ST4) We have no good reason for thinking that the total moral value or disvalue we perceive in certain complex states of affairs accurately reflects the total moral value or disvalue they really have (Bergmann, 2001).

\section{Skeptical Theism and Common-Sense Epistemology}

According to an objection moved, among the others by Dougherty $(2008)^{1}$, ST would go against against Common Sense Epistemology. Consider the following two principles:

Chrisholm 'Principle of Immediate Justification. (PI)

[W] henever you have an experience as of $\mathrm{p}$, you thereby have immediate prima facie justifcation for believing $\mathrm{p}$

1 For a recent overview of the debate surrounding ST see Dougherty, 2014. For a useful anthology of recent essays on ST see Dougherty and McBryer (eds), 2014 


\section{Huemer'S Principle of Phenomenal Conservatism. (PC)}

If it seems to $S$ as if $\mathrm{p}$, then $\mathrm{S}$ thereby has at least prima facie justification for believing that $\mathrm{p}$.

PI, PC are among the various "Moorean" anti skeptical strategies that are generally employed against Radical Skepticism. The feature of Radical Skeptical arguments is that we cannot know certain empirical propositions (such as 'Human beings have bodies', or 'There are material objects') as we may be dreaming, hallucinating, deceived by a demon or be "brains in the vat" (BIV), that is, disembodied brains floating in a vat, connected to supercomputers that stimulate us in just the same way that normal brains are stimulated when they perceive things in a normal way. ${ }^{2}$ Therefore, as we are unable to refute these skeptical hypotheses, we are also unable to know propositions that we would otherwise accept as being true if we could rule out these scenarios.

Let's take a skeptical hypothesis, $\mathrm{SH}$, such as the BIV hypothesis mentioned above, and $\mathrm{M}$, an empirical proposition such as "Human beings have bodies" that would entail the falsity of a skeptical hypothesis. We can then state the structure of Cartesian skeptical arguments as follows:

(S1) I do not know not-SH

(S2) If I do not know not-SH, then I do not know M

(SC) I do not know M

Considering that we can repeat this argument for each and every one of our empirical knowledge claims, the radical

2 See Putnam (1981). 
skeptical consequence we can draw from this and similar arguments is that our knowledge is impossible.

In the literature on Radical Skepticism, PI and PC are usually employed in order to refute the first premise S1) of the Radical Skeptical argument; roughly, the idea is that following these two "common-sense informed" epistemic principles, we are prima facie justified in believing that our perceptions are generally reliable and we are thus not the victim of a skeptical scenario.

As per Dougherty, a proponent of ST would be implicitly committed to go against common- sense epistemology. This is so, he argues, because following either PI or PC, it would seem that then we are least prima facie justified in believing that

E1) There exist instances of intense suffering which an omnipotent, omniscient being could have prevented without thereby losing some greater good or permitting some evil equally bad or worse

as we are prima facie justified to take for granted the general reliability of our senses and thus fact that we are not victim of a skeptical scenario. Accordingly, a proponent of ST will be forced to either abandon common-sense informed antisceptical common-sense informed epistemic strategies or to agree with skeptical conclusions.

The debate on the anti-skeptical implications of common-sense epistemology is huge and to discuss its merits in detail will go beyond the scope of the present paper. Here, I will just present a couple of criticisms that are more relevant for the problem at issue.

A first problem for "common-sense informed "antiskeptical strategies is that it seems to underestimate the difference between practical and theoretical rationality (Pritchard, 2005). 
That is to say, if in our ordinary, day to day life it would be irrational not to follow PI, PC or some other "common sense informed " epistemological viewpoints, things are more complicated while doing philosophy, for instance when Skeptical arguments are in play. Hence, the anti-skeptical force of "common sense epistemology" is somewhat moot.

Moreover, and more importantly, PI and PC can be easily reformulated along "Theistic" lines, with somewhat implausible consequences. Take the following principles:

\section{Principle of Immediate Theistic Credulity}

(PTI) [W] henever you have a religious experience as of $\mathrm{p}$ (i.e. God exist, There is an order in this world that can only be the result of the action of an all loving all powerful God, etc), you thereby have immediate prima facie justification for believing $\mathrm{p}$

\section{The Principle of Theistic Phenomenal Conservatism.} (PTC)

If it seems to $\mathrm{S}$ as if $\mathrm{p}$ (i.e. "I hear God speaking to me ", "I see Our Lady while looking at the sky, etc), then $S$ thereby has at least prima facie justification for believing that $\mathrm{p}$.

Now, PTI and PTC are hardly convincing; then why should $\mathrm{PI}$ and PC be any better?

The appeal to common sense epistemology, then, is not only problematic as an anti skeptical strategy, but it can also lead to some unpalatable consequences when it comes to Theistic or anti Theistic beliefs. 


\section{Skeptical Theism and Empirical Falsifiability}

A second objection against ST goes as follows. According to Wilks (2009) ST is implicitly committed to the following principle

(U) Every claim about God is empirically unfalsifiable

This is so because skeptical theism is telling that we should discard the strong evidential claim that support the first premise of the Evidential Problem of Evil, namely

E1) There exist instances of intense suffering which an omnipotent, omniscient being could have prevented without thereby losing some greater good or permitting some evil equally bad or worse.

As a result, ST will license a number of implausible claims. Consider the following exchange:

"If God made the world less than 10,000 years ago, why does the world contain geological evidence suggesting otherwise?"

U based response:

a) The world may contain geological evidence suggesting otherwise because of an unknown strategy of carrying out what was involved, less than 10,000 years ago, in creating the world.

That is to say, $\mathrm{U}$ allows us to discount any and all empirical evidence against the claim that the planet earth is less than 10,000 years old. 
Moreover, argues Wilks, $\mathrm{U}$ allows for a number of literal interpretations of religious texts; for example, it will allow for

b) a literal reading of Joshua 10: 12-13, in which the sun is depicted as having been caused by God to stand still in the sky for the duration of about a day.

A proponent of ST can find these claims unreasonable, but according to Wilks, skeptical theists must accept the rationality of defending the claims a) and b) by these means; for ST, by inviting us to ignore the evidential evidence in support of the evidential problem of Evil, is implicitly committed to $\mathrm{U}$, no differently from the Biblical literalist such as a) and b) claims we have mentioned.

This is is because when we allow ourselves to discounting strategies (for instance by ignoring the relevance of empirical evidence), we open the door to a number of irrational- disconcerting conclusions.

A first objection that could be raised against this criticism of ST is that the first premise of the Evidential problem of Evil, namely

E1) There exist instances of intense suffering which an omnipotent, omniscient being could have prevented without thereby losing some greater good or permitting some evil equally bad or worse.

does not enjoy the strong evidential support of "hard sciences", and is thus constitutively different from scientific claims such as" The earth is approx. 4,5 billions years old" or "The earth orbits around the sun".

This is so because questions about the gratuity of evil are more similar to questions about the meaning of life than to 
empirical questions about the age of the Earth: they involve a number of theoretical commitments, values, and assumptions that fall beyond the scope of empirical inquiry. Hence the parallel between scientific empirical claims and E1) is misguided in the first place.

\section{Skeptical Theism and Moral Myopia}

Another criticism that has been recently raised against ST is that this proposal will lead to a number of unpalatable consequences on our capacity for moral deliberation. In order to understand this point, recall the first three premises of Bergmann's argument in defence of ST:

(ST1) We have no good reason for thinking that the possible goods we know of are representative of the possible goods there are

(ST2) We have no good reason for thinking that the possible evils we know of are representative of the possible evils there are.

(ST3) We have no good reason for thinking that the entailment relations we know of between possible goods and the permission of possible evils are representative of the entailment relations there are between possible goods and the permission of possible evils.

As per Jordan (2006), anyone who accepts the Premises ST1ST3 will be lead to Moral Myopia (Jordan, 2006); that is, to the impossibility to judge whether an action should or should be not performed All Things Considered (henceforth ATC). This is so because once we assume that we are constitutively unable to understand the possible good or bad future consequences of an action, it will be impossible to, for instance, be entitled to perform a good action $\mathrm{x}$ or prohibit 
a bad action $\mathrm{y}$ as both $\mathrm{x}$ could well have unforeseeable bad consequences while y could have, ATC, unpredictable good ones.

Jordan recognises that ST will have these somewhat unpalatable consequences on someone committed to Deontic or Utilitarian ethical doctrines, while it does not necessarily affect an ethical tradition such as the Natural Law Theory (henceforth NLT).

Roughly, according to NLT there are acts that are intrinsically evil; hovewer, we can tolerate intrinsically evil acts if to repress them will lead to greater evils. As Aquinas puts the matter

\begin{abstract}
"Now although God is all-powerful and supremely good, nevertheless He allows certain evils to take place in the universe, which $\mathrm{He}$ might prevent, lest, without them, greater goods might be forfeited, or greater evils ensue. Accordingly in human government also, those who are in authority, rightly tolerate certain evils, lest certain goods be lost, or certain greater evils be incurred. $(1947,56)$
\end{abstract}

According to Jordan, ST will lead to a 'mutilated' version of the NLT, as it will undermine our capacity to discriminate between tolerable and intolerable evils; what appears as an intolerable evil might not, ATC, be one.

However, an important point top notice is that NLT stresses our fallibility: this is why, for instance there is a certain debate about what evils should or should not be allowed in NLT and more generally about the implementations of the social aspects of NLT. Hence, once applied to NLT, ST might lead at most to some sort of healthy moral epistemic bumility and not to an, unhealthy, moral myopia. 
This is so because if "we can tolerate intrinsically evil acts if to repress them will lead to greater evils" is valid for fallible human beings, it should be also valid for an Omniscient, Omnipotent God that, according to a Theist, knows always what He is doing. Accordingly, rather than "mutilating" NLT, ST is totally compatible with $i$

\section{Skeptical Theism and Divine Lies}

A more recent line of criticism against ST has been recently put forward by Law $(2015,2017)$

As we have seen, ST criticizes the "noseeum" inference from

i) we can't think of any reason God might have for creating and allowing evils

To

ii) there are no reasons that God might have for creating and allowing evils.

Due to both our cognitive limitations and the limits of the evidence available to us, we are not in a position to conclude that ii) from i).

With this point in mind, we can now go back to Law's argument. He invites us to imagine the following situation: we are watching through a window a series of widgets passing by on an assembly line. The widgets clearly look red; as the widgets appear red to us, it is reasonable for us to form the belief 


\section{a) "The widgets are red"}

We are then told by a reputable source of information $\mathrm{x}$ that the widgets are lit by a particular light that makes nonred objects look red.

Now, asks Law, is it still reasonable for us to believe that a) "The widgets are red"? His answer is no, as we now have reasons to doubt the reliability of the methods by which we have formed the belief a).

This is because "The widgets are lit by a special light that makes non-red objects look red "is a rationality defeater, as it undermines the rationality of our belief in a).

In a similar fashion, argues Law, ST is a rational defeater, as it undermines the rationality of our belief about the external world and the past. Suppose that we are told by a reliable source that

$\left.i^{*}\right)$ God exists

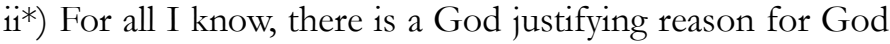
to deceive me about the external world and the past we can no longer reasonably believe in the rationality of our belief about the external world or the past.

This is because if the "nooseum inference from

i) "I can't see any reason that God might have to allow this evil"."

to ii) There is no reason that God might have to allow these evils"."

Is illegitimate, then the inference from

$\left.i^{*}\right)$ "I can't see any reason that God might have to deceive me about the external world and the past"." 
to

ii*) "There is no reason that God might have to deceive me about the external world and the past" is illegitimate as well.

That is to say, argues Law, once we assume that God can have impenetrable reasons in order to allow a certain evil $\mathrm{x}$ and that this could be enough in order to undermine the plausibility of the premises of the EAE then we could also assume that God could also have inscrutable reason to systematically deceive about the existence of the external world and of the past. Moreover, argues Law, this will not only undermine our confidence in the existence of the external world and of the past; it will also undermine our confidence in the basic tenets of Theism ${ }^{\mathrm{i}}$ and especially of Revealed religions such as Christianity; if God might have inscrutable reasons to lie about the existence of the past and of the external world, He could well have inscrutable reasons to deceive us about the principal doctrines of Christian Theism.

A first criticism that can be raised against this objection to ST is that it draws a somewhat unconvincing parallelism between The God of Classical Theism and a Cartesian Evil Deceiver, or the BIV mad scientists or other well-known characters of "epistemological folklore".."

Remember that EAE is supposed to undermine and, more importantly, only works within the Theistic framework; that is, EAE is meant to stress the prima facie implausibility of the existence of the Omnipotent, Omniscient and Omnibenevolent God of Classical Theism given the huge amount of evil in the world. A point that has been made, among the others, by one of the principal proponent of the arguments from evil, namely J.L Mackie, who affirms that The problem of evil, in the sense in which I shall be using the phrase, is a problem only for someone who believes that there is a God who is both omnipotent and wholly good' $(1955,200)$. In a 
similar fashion, Michael Martin, writes that 'the problem of evil presumably does not show that God does not exist when "God" refers to some being that is either not omnipotent or not completely benevolent'.

Hence, EAE is aimed at, first and foremost, a God which is Morally Perfect, to the extent that, if it was aimed at a deity that "lacked" moral perfection, the argument would not work.

Among the various attributes of the God of Classical Theism, there is Moral Perfection; that is to say, sinlessness. Roughly, the God of Theism cannot sin, and crucially cannot sin because he is all Perfect; if he were to sin, He would not be perfect.

This point is stated by various authors committed to Classical Theism such as Boethius, Anselm and Aquinas. Consider the following passages:

"God is omnipotent...there is nothing that an omnipotent power could not do..Then can God do Evil? No (Boethius, 1969, bk 3 c.12 p. 112)"

"[God] is not able to be corrupted or to tell a lie" (Anselm, 1974, c.7, p.97)

“..to $\sin$ is to fall short of a perfect action; hence, to be able to sin is to be able to fall short in action, which is repugnant to omnipotence. Therefore...God cannot sin, because of His omnipotence (Aquinas, ST, 1 a25, 3 ad2)

What is important to notice is that the fact that God cannot sin is not a limitation of his freedom but is actually a consequence of, using Mawson's expression $(2005,67)$ his perfect freedom; that is to say, he does not have all the 
intellectual and moral limitations that hamper the freedom of finite beings such as ourselves and lead us into error .

Now, to deceive, whether systematically or not, someone about $\mathrm{x}$ amount to make someone falsely believe that $x$; and to make falsely believe to someone that $\mathrm{x}$ is nothing less than false testimony; and false testimony is a sin.

Crucially, while is at least logically possible than a Benevolent, Omnipotent Being could tolerate $\sin ^{\mathrm{ii}}$, to assume that there is an Omnipotent, Omniscient, All-Loving, Morally Perfect Being that at the same time constantly sins by deceiving us about the existence of the external world or of the past is to assume a logical contradiction, no different from assuming the existence of a "Square with five sides".

\section{Concluding Remarks}

In this paper, I have argued that a number of recent criticisms moved against ST are wanting. Also, I have argued that once seen in the light of the attributes of the God of Classical Theism, namely Moral Perfection and Omniscience, ST amount to nothing but to a recognition of our cognitive limitations and does not undermines our everyday and Theistic beliefs. ST can still be considered, then, a valid response to the EAE and does not lead to other unpalatable epistemological conclusions.

\section{References}

AQUINAS, T, (1265-1274), Summa Theologiae, in Summa Theologiae: Questions on God, B. Davies and B. Leftow (eds.), Cambridge: Cambridge University Press, 2006.

BEEBE, J.R., "The Logical Problem of Evil", Internet Encyclopedia of Philosophy, access date 16-10-2019 
BERGMANN, M. (2001) "Skeptical Theism and Rowe's New Evidential Argument from Evil," Nous 35, pp. 278-296

DOUGHERTY, T. (2014) Skeptical Theism", The Stanford Encyclopedia of Philosophy (Winter 2016 Edition), Edward N. Zalta (ed.), URL = $<$ https://plato.stanford.edu/archives/win2016/entri es/skeptical-theism/>. . and MCBRAYER, J. (eds), (2014), Skeptical Theism: New Essays, Oxford: Oxford University Press.

DURSTON, K. (2000) "The consequential complexity of history and gratuitous evil," Religious Studies 36, pp. 6580.

JORDAN, J. (2006) "Does Skeptical Theism Lead to Moral Skepticism?" Philosophy and Phenomenological Research 72, pp. 403-416

LAW, S. (2017), "Skeptical theism and Skepticism About the External World and Past", Royal Institute of Philosophy Supplement 81 55-70.

. (2015), “The Pandora's box objection to skeptical theism, International Journal for Philosophy of Religion 78 (3): 285-299.

MACKIE, J. L. (1955). "Evil and Omnipotence." Mind 64: 200-212.

PLANTINGA, A. (1974). God, Freedom, and Evil. Grand Rapids, MI: Eerdmans.

ROWE, W. (1979) "The Problem of Evil and Some Varieties of Atheism," American Philosophical Quarterly 16, pp. $335-41$ 
WIELEMBERG, E. (2010), Sceptical theism and divine lies. Religious Studies, 46, pp 509-523, doi:10.1017/S0034412510000247

WILKS, I. (2009) "Skeptical Theism and Empirical Unfalsifiability," Faith \& Philosophy 26:1, pp. 64-76.

WYSKRA, S. (1984) "The Humean Obstacle to Evidential Arguments from Suffering: On Avoiding the Evils of 'Appearance'," International Journal of Philosophy of Religion 16, pp. 73-93.

$(c c) B Y$

i For a similar criticism of ST, see also Wienenberg, 2010

ii The logical problem of evil, for which the existence of the Theistic God would be incompatible with the evils of the world, has been famously defended by Mackie (1955); however, due to the influential work of Plantinga (1974) this version of the problem of evil has been generally considered as unsuccessful. For a recent overview of the debate surrounding this issue, see Beebe (access date 16-10-2019)

Manuscrito - Rev. Int. Fil. Campinas, v. 44, n. 4, pp. 293-312, Oct.-Dec. 2021. 